\title{
DEVELOPMENT OF AN EFFICIENT MICROPROPAGATION PROTOCOL FOR EUCALYPTUS HYBRID (E. UROPHYLLA $\times$ E. GRANDIS) THROUGH AXILLARY SHOOT PROLIFERATION
}

\author{
Nazirah A*, Nor-Hasnida H, Mohd-Saifuldullah AW, Muhammad-Fuad Y, Ahmad-Zuhaidi Y \& \\ Rozidah K
}

Forestry Biotechnology Division, Forest Research Institute Malaysia, 52109, Kepong, Selangor, Malaysia

*nazirah@frim.gov.my

Submitted December 2019; accepted January 2021

\begin{abstract}
Eucalypts, in the family of Myrtaceae, are a fast-growing timber able to adapt to marginal environments. In Malaysia, the Eucalyptus hybrid (E. urophylla $\times$ E. grandis) is becoming popular for plantation as it is more tolerant to disease and produces a straight bole. Micropropagation of axillary shoots from a healthy Eucalyptus hybrid mother tree was evaluated for shoot proliferation in Murashige and Skoog (MS) basal media and woody plant media (WPM), supplemented with 0.1, 0.5, 1.0, 2.0 and $3.0 \mathrm{mg} \mathrm{L}^{-1}$ 6-benzylaminopurine (BAP), singly or in combination with $0.5,1.0$ and $2.0 \mathrm{mg} \mathrm{L}^{-1} 1$-naphthaleneacetic acid (NAA). The WPM and MS basal media supplemented with $0.1 \mathrm{mg} \mathrm{L}^{-1}$ BAP were found suitable for shoot multiplication as both media induced the production of new shoots and shoot elongation. Higher concentration of BAP and NAA produced stunted axillary shoots. Regenerated shoots were evaluated for root growth in half strength MS basal media supplemented with indole-3-butyric acid (IBA) or NAA at concentrations 0.5, 1.0, 2.0 and $3.0 \mathrm{mg} \mathrm{L}^{-1}$. Root produced and root lengths were not significantly different among media formulation, and it was observed that $0.5 \mathrm{mg} \mathrm{L}^{-1} \mathrm{IBA}$ in $1 / 2 \mathrm{MS}$ basal medium gave the best overall root production. Healthy regenerated plantlets were acclimatised in a weaning chamber for one month, and then planted in polybags filled with baked soil and peat moss (1:1). The plantlets were watered twice a day and kept under $50 \%$ shade in the nursery until ready to be transplanted into open field.
\end{abstract}

Keywords: Tissue culture, shoot multiplication, root induction, plantlets, nursery

\section{INTRODUCTION}

Eucalyptus spp., in the family of Myrtaceae, native to Australia and nearby islands, is a versatile fastgrowing hardwood tree. This is a large genus of more than 700 species, many of which are well adapted to marginal environments and show faster or superior growth than other tree species (Henry \& Kole 2014). Eucalyptus timber is widely used for producing pulp, paper, and plywood for furniture while essential oils extracted from the leaves are used in pharmaceutical products and as a natural pesticide (Batish et al. 2008).

In Malaysia, Eucalytus grandis and E. deglupta plantations were established beginning in 1974 in Sabah, but these species were phased out due to poor growth performance. Interest in planting Eucalyptus has recently revived, as E. pellita and Eucalyptus hybrids poised to replace Acacia mangium as the most preferred plantation species. This is due to the characteristic of these eucalypts, which, apart from having a desirable straight bole, were also resistant to Ceratocytis. The Ceratocytis is a major disease afflicting
A. mangium, once a major crop for plantation in Sabah which had caused loss to planters (Ahmad Zuhaidi 2019, Lee 2003). Besides the good wood quality and disease resistance, the rotation length of Eucalyptus plantations is shorter compared to other hardwood species; 5-7 years for Eucalyptus hybrid and 5 years for E. pellita (Hardwood 2014).

The sustainable production of good quality planting material is an important aspect for the establishment of commercial Eucalyptus forest plantation. Eucalyptus is propagated from seed, vegetatively from coppice cuttings and tissue culture technology. The latter is becoming an increasingly popular method to obtain planting material because it can multiply plantlets faster than conventional methods, and can be produced continuously throughout the year. In addition, Eucalyptus hybrid seeds are expensive and short of supply, and macropropagation success with hybrid clone cuttings is poor due to low rooting rates (Brondani et al. 201, 2012). 
The potential of Eucalyptus hybrid has been recognised in the forestry industry where there have been many attempts for mass plantlets production, especially with in vitro methods. Eucalyptus hybrid clones (E. urophylla $\times$ E. grandis) have been produced in several countries such as Brazil, China and South Africa (Brondani et al. 2011, Oliveira et al. 2017, Xie et al. 2017). The media nutrients required by these $E$. hybrids were found to be different. Although the hybrid is from the same species, the parent trees used for the initiation of tissue culture are from different clones and individuals. In tissue culture, there are differences in nutrient media requirements and growth hormones for different clones, even from the same species (Oliveira et al. 2017). In this study, the main mother tree was planted in Malaysia and was selected because it showed good growth and quality of wood. Thus, there is a need to develop tissue culture protocols to propagate the mother tree.

\section{MATERIALS AND METHODS}

Plant material collection and culture initiation Eucalyptus hybrid shoots were collected from a mother tree planted in Bukit Hari, Selangor. The shoots were cut and wrapped with wet tissue, and stored in plastic bags to remain the moisture, and transported to the laboratory within two hours. The young shoots were surface-sterilised with $70 \%$ (v/v) ethanol for 1 minute, followed by $50 \%$ Clorox ${ }^{\circledR}$ for 20 minutes and subsequently rinsed with sterile distilled water for five times. The cleaned shoots were cultured vertically on Murashige and Skoog (MS) basal medium containing $30 \mathrm{~g} \mathrm{~L}^{-1}$ sucrose and $3 \mathrm{~g} \mathrm{~L}^{-1}$ gelrite agar, supplemented with $0.25 \mathrm{mg} \mathrm{L}^{-1} \mathrm{BAP}$, and $\mathrm{pH}$ set at 5.8 to induce shoot initiation (Murashige \& Skoog 1962). The cultures were incubated under 16 hours of light with intensity of 2000 lux, at a constant temperature of $22 \pm 0.2^{\circ} \mathrm{C}$ for 5 weeks.

\section{Shoot multiplication}

At the end of the initiation period, the axillary shoots induced were subcultured into shoot multiplication media. Two basal media, MS medium and woody plant media (WPM), supplemented with varying concentrations of BAP and 1-naphthaleneacetic acid (NAA), either singly or in combination, were used. All other media ingredients and culture conditions were kept the same as in the culture initiation period. The number and length of shoots were measured after four weeks in culture. The experiment was replicated with 15 shoots per treatment.

\section{In vitro rooting}

Regenerated shoots, $\geq 1.5 \mathrm{~cm}$ long were transferred to rooting media containing various combinations of half strength MS basal media, supplemented with the auxins, indole-3-butyric acid (IBA) or NAA at concentrations 0.5, 1.0, 2.0 and $3.0 \mathrm{mg} \mathrm{L}^{-1}, 30 \mathrm{~g} \mathrm{~L}^{-1}$ sucrose and $3 \mathrm{~g} \mathrm{~L}^{-1}$ Gelrite ${ }^{\circledR}$. The number of rooted shoots, roots per shoot and root length were recorded after two weeks. In this study, all media for shoot initiation, shoot multiplication and in vitro rooting were adjusted to $\mathrm{pH} 5.8$, and then autoclaved at $121^{\circ} \mathrm{C}$ for 15 minutes before use.

\section{Acclimatisation of plantlets}

Plantlets were carefully washed to remove agar and dipped into $0.1 \%(\mathrm{v} / \mathrm{v})$ fungicide, and planted in Jiffy $7{ }^{\circledR}$ pellets, a compressed mixture of coconut peat and peat moss. These regenerated plantlets were then acclimatised in a weaning chamber for one month. Humidity was maintained at $90 \%$, and then gradually reduced after one month by removing the cover. The survival percentage of the plantlets was assessed after a month of acclimatisation in the chamber with the cover fully removed.

\section{Data analysis}

Tukey's honestly significant difference (HSD) test $(p=0.05)$ was performed when significant differences among treatments were detected by analysis of variance (ANOVA). The analyses were performed with SAS version 9.1.2 (SAS Institute Inc., Cary, NC, 2000).

\section{RESULTS AND DISCUSSION}

\section{Shoot multiplication}

Culture media supplemented with BAP or NAA, either singly or in combination, induced more shoots than the control without addition of the plant growth regulator (PGR) (Table 1, Figure $1)$. The MS basal medium supplemented with $0.5 \mathrm{mg} \mathrm{L}^{-1} \mathrm{BAP}$ had the highest number of shoots 
per explant $(5.9 \pm 0.4)$; significantly greater $(\mathrm{p}<0.001)$ than the control $(3.7 \pm 0.3)$ but not significantly different from shoots produced on other MS basal media treatments. Meanwhile, in WPM basal media, the highest shoot production of $7.4 \pm 0.4$ was obtained in $0.1 \mathrm{mg} \mathrm{L}^{-1} \mathrm{BAP}$ and $0.5 \mathrm{mg} \mathrm{L}^{-1} \mathrm{NAA}$ supplementation, significantly greater than control $(3.0 \pm 0.3, p<0.0001)$ but not significantly different from shoot produced on other WPM treatments, except for $1.0 \mathrm{mg} \mathrm{L}^{-1} \mathrm{BAP}$.

When supplemented with BAP alone, shoot produced on MS basal media increased as BAP concentration increased, peaking at $5.9 \pm 0.4$ (with $0.5 \mathrm{mg} \mathrm{L}^{-1} \mathrm{BAP}$ ) and reduced thereafter with increasing concentrations, however, these differences were not significant. Multiple effects of BAP at different concentrations have been reported in other $E$. hybrid cultures; BAP concentrations higher than $0.5 \mathrm{mg} \mathrm{L}^{-1}$ have been shown to reduce shoot multiplication in $E$. benthamii $\times E$. dunni and E. globulus, while $1.0 \mathrm{mg} \mathrm{L}^{-1}$ BAP with $1 \mathrm{mg} \mathrm{L}^{-1} \mathrm{NAA}$ induced higher shoot multiplication for $E$. tereticornis $\times E$. grandis and E. tereticornis $\times$ E. camaldulensis (Bennet et al. 1994, Bisht et al. 1999, Joshi et al. 2003, Brondani et al. 2011).
In this study, the addition of BAP in WPM basal media significantly increased the shoot multiplication, compared to WPM basal media without addition of PGR. However, the BAP effects among the concentrations $\left(0.1-3.0 \mathrm{mg} \mathrm{L}^{-1}\right)$ were varied and the increment of shoots was not in parallel with the increment of BAP concentrations added into the media. Hence, it was difficult to make a correlation between BAP concentration and E. hybrid shoot multiplication in WPM basal media. However, the differences in the number of shoots between BAP concentrations were insignificant. It was noted that, while not quantified, WPM basal medium supplemented with $0.1 \mathrm{mg} \mathrm{L}^{-1}$ BAP produced more leaves, which appeared larger and healthier than those in the other treatments (Figure 1, WPM1).

The combination of two PGR, BAP and NAA showed an increase in the production of $E$. hybrid shoots in both MS and WPM basal media. Based on statistical analysis, the combined effect of two PGR showed a significant increase in the number of shoots in WPM basal media, compared with controls. Statistical analysis showed that shoot production between different NAA concentrations were insignificantly different.

Table 1 Effects of different basal media supplemented with plant growth regulators (PGR) on the production of new shoots and shoot length, at four weeks of culture

\begin{tabular}{|c|c|c|c|c|c|}
\hline Treatment & $\begin{array}{l}\text { Mean no of } \\
\text { new shoots }\end{array}$ & $\begin{array}{c}\text { Shoot } \\
\text { length }(\mathrm{cm})\end{array}$ & $\begin{array}{l}\text { Level treatment } \\
\text { (BAP, NAA }) \\
(\mathrm{mg} / \mathrm{L})\end{array}$ & $\begin{array}{l}\text { Mean no of new } \\
\text { shoots }\end{array}$ & $\begin{array}{l}\text { Shoot length } \\
\quad(\mathrm{cm})\end{array}$ \\
\hline \multirow{9}{*}{ MS } & \multirow{9}{*}{$4.911^{\mathrm{b}}$} & \multirow{9}{*}{$0.755^{\mathrm{a}}$} & $(0,0)$ & $3.7 \pm 0.33^{\mathrm{b}}$ & $1.05 \pm 0.1^{\mathrm{b}}$ \\
\hline & & & $(0.1,0.0)$ & $5.33 \pm 0.48^{\mathrm{ab}}$ & $1.74 \pm 0.09^{\mathrm{a}}$ \\
\hline & & & $(0.5,0.0)$ & $5.9 \pm 0.44^{\mathrm{a}}$ & $0.94 \pm 0.05^{b c}$ \\
\hline & & & $(1.0,0.0)$ & $4.4 \pm 0.53^{\mathrm{ab}}$ & $0.51 \pm 0.05^{\mathrm{de}}$ \\
\hline & & & $(2.0,0.0)$ & $4.26 \pm 0.37^{\mathrm{ab}}$ & $0.52 \pm 0.03^{\mathrm{de}}$ \\
\hline & & & $(3.0,0.0)$ & $4.23 \pm 0.38^{\mathrm{ab}}$ & $0.31 \pm 0.03^{\mathrm{e}}$ \\
\hline & & & $(0.1,0.5)$ & $5.27 \pm 0.44^{\mathrm{ab}}$ & $0.77 \pm 0.07^{\mathrm{cd}}$ \\
\hline & & & $(0.1,1.0)$ & $5.73 \pm 0.4^{\mathrm{a}}$ & $0.5 \pm 0.03^{\mathrm{de}}$ \\
\hline & & & $(0.1,2.0)$ & $5.37 \pm 0.38^{\mathrm{ab}}$ & $0.44 \pm 0.06^{\mathrm{e}}$ \\
\hline \multirow{9}{*}{ WPM } & \multirow{9}{*}{$5.996^{\mathrm{a}}$} & \multirow{9}{*}{$0.616^{\mathrm{b}}$} & $(0,0)$ & $3.03 \pm 0.29^{c}$ & $1.08 \pm 0.09^{\mathrm{a}}$ \\
\hline & & & $(0.1,0.0)$ & $6.23 \pm 0.33^{\mathrm{ab}}$ & $1.16 \pm 0.08^{\mathrm{a}}$ \\
\hline & & & $(0.5,0.0)$ & $6.33 \pm 0.31^{\mathrm{ab}}$ & $0.64 \pm 0.06^{\mathrm{b}}$ \\
\hline & & & $(1.0,0.0)$ & $5.9 \pm 0.32^{\mathrm{b}}$ & $0.55 \pm 0.04^{\mathrm{bcd}}$ \\
\hline & & & $(2.0,0.0)$ & $6.5 \pm 0.27^{\mathrm{ab}}$ & $0.38 \pm 0.02^{\mathrm{cd}}$ \\
\hline & & & $(3.0,0.0)$ & $6.2 \pm 0.19^{\mathrm{ab}}$ & $0.38 \pm 0.04^{\mathrm{cd}}$ \\
\hline & & & $(0.1,0.5)$ & $7.4 \pm 0.42^{\mathrm{a}}$ & $0.59 \pm 0.05^{b c}$ \\
\hline & & & $(0.1,1.0)$ & $6.27 \pm 0.34^{\mathrm{ab}}$ & $0.4 \pm 0.02^{\mathrm{cd}}$ \\
\hline & & & $(0.1,2.0)$ & $6.1 \pm 0.35^{\mathrm{ab}}$ & $0.36 \pm 0.02^{\mathrm{d}}$ \\
\hline
\end{tabular}

Means with different letters in each column are significantly different (Tukey's HSD test); $\mathrm{BAP}=$ benzyladeninepurine, NAA = naphthalene acetic acid, MS = Murashige and Skoog, $\mathrm{WPM}=$ woody plant medium 

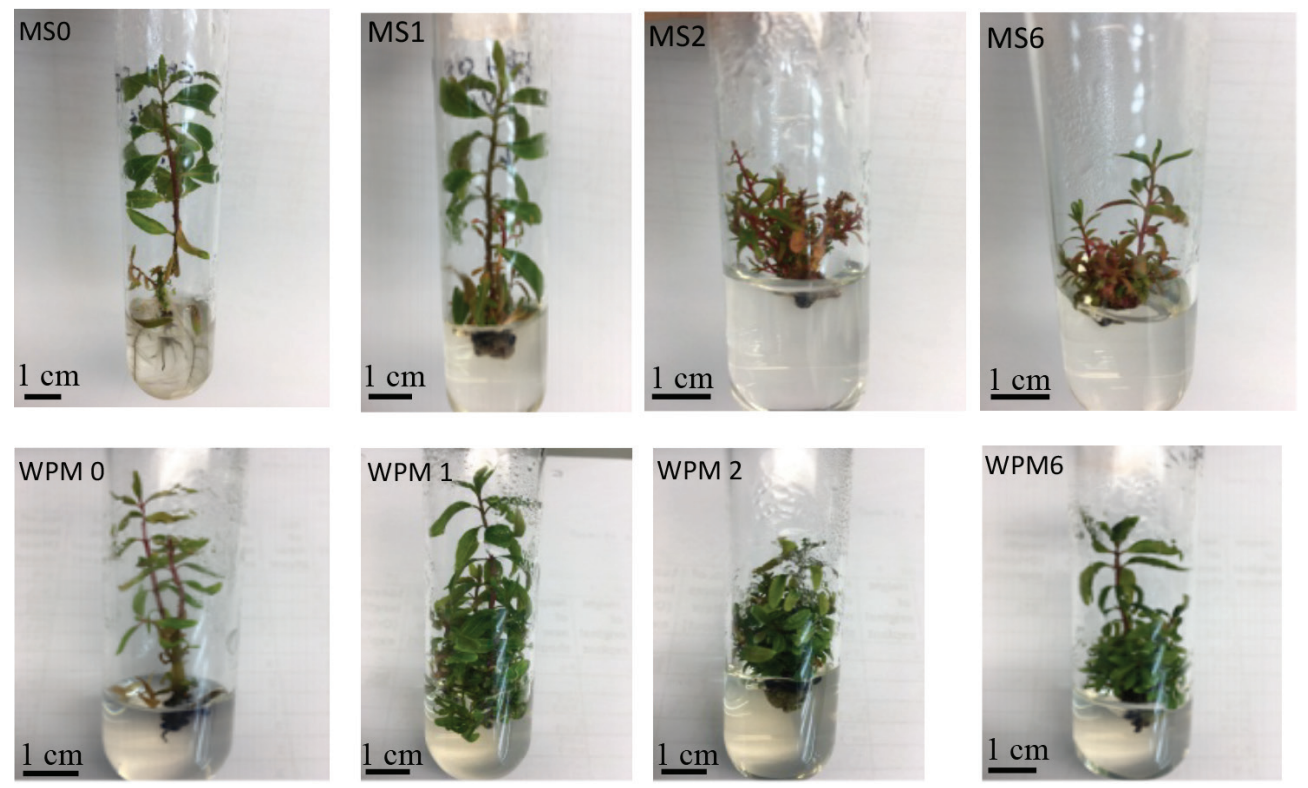

Figure 1 Growth of Eucalyptus hybrid shoots cultured on MS and WPM basal media supplemented with different concentrations of plant growth regulators (PGR): MS0 = no PGR, MS1 $=+0.1 \mathrm{mg} \mathrm{L}^{-1}$ BAP, MS2 = + $0.5 \mathrm{mg} \mathrm{L}^{-1} \mathrm{BAP}, \mathrm{MS} 6=+0.1 \mathrm{mg} \mathrm{L}^{-1} \mathrm{BAP}+0.5 \mathrm{mg} \mathrm{L}^{-1} \mathrm{NAA}$, WPM0 = no PGR, WPM1 $=+0.1 \mathrm{mg} \mathrm{L}^{-1} \mathrm{BAP}$, WPM2 $=+0.5 \mathrm{mg} \mathrm{L}^{-1} \mathrm{BAP}$, WPM $6=+0.1 \mathrm{mg} \mathrm{L}^{-1} \mathrm{BAP}+0.5 \mathrm{mg} \mathrm{L}^{-1} \mathrm{NAA}$

The addition of NAA did not show a significant difference with BAP treatment alone (0.1$3.0 \mathrm{mg} \mathrm{L}^{-1}$ ), in both MS and WPM basal media for total shoot production. Based on these results, PGR combination can be used for E. hybrid shoot multiplication, however, the treatment with single BAP is sufficient if production cost is the main concern. Previous media formulation assessments for $E$. urophylla $x E$. grandis have reported that MS basal media supplemented with $0.5 \mathrm{mg} \mathrm{L}^{-1} \mathrm{BAP}$, without the addition of auxin, induced maximum shoot proliferation, while WPM basal media supplemented with $0.11 \mathrm{mg} \mathrm{L}^{-1}$ $(5.0 \mu \mathrm{M}) \mathrm{BAP}$ and $0.1 \mathrm{mg} \mathrm{L}^{-1}(0.5 \mu \mathrm{M}) \mathrm{NAA}$ induced the best regeneration of shoots from callus (Ma et al. 2016, Oliveira et al. 2017).

In tissue culture, the selection of the best PGR for shoot multiplication should take into account the effect of PGR on the elongation of new shoots produced. High concentrations of PGR applied in culture medium may induce vigorous shoot production, but with side effects of rendering new shoot growth, abnormal shoot and sometimes difficulty to root. In this study, shoot length was measured at $1.7 \pm 0.1 \mathrm{~cm}$ for explants cultured in MS medium to which $0.1 \mathrm{mg} \mathrm{L}^{-1} \mathrm{BAP}$ was added; where significantly longer shoot length were observed, compared to control $(1.1 \pm 0.1 \mathrm{~cm}$, $\mathrm{p}<0.001)$. Further BAP increments significantly reduced new shoots growth, compared to control.
The WPM supplemented with $0.1 \mathrm{mg} \mathrm{L}^{-1} \mathrm{BAP}$ yielded slightly longer shoots $(1.2 \pm 0.1 \mathrm{~cm})$ than control $(1.1 \pm 0.1 \mathrm{~cm})$, however the difference was not significant. However, increasing BAP concentrations above $0.5 \mathrm{mg} \mathrm{L}^{-1}$ reduced shoot lengths significantly $(\mathrm{p}<0.0001)$. The addition of auxin, $0.5 \mathrm{mg} \mathrm{L}^{-1} \mathrm{NAA}$ in combination with $0.1 \mathrm{mg} \mathrm{L}^{-1}$ BAP, yielded shoots that were significantly shorter in both MS and WPM media $(0.8 \pm 0.1$ and $0.6 \pm 0.1 \mathrm{~cm}$, respectively, $\mathrm{p}<0.0001)$. The combination of hormones PGR, BAP and NAA did not assist in the elongation of new shoots, compared to single BAP $\left(0.1 \mathrm{mg} \mathrm{L}^{-1}\right)$ and control (Figure 1). Multiple shoots with stunted growth of $E$. hybrid were observed in media with NAA (MS6 and WPM6).

Based on the results, MS and WPM basal media supplemented with $0.1 \mathrm{mg} \mathrm{L}^{-1}$ BAP were found to be suitable for shoot multiplication, as both induced the production of new shoots and shoot elongation in multiplication stage. Therefore, shoot elongation phase was not required and this is an advantage for commercial production where shorter time is required to obtain plantlets, with lower cost. Further consideration on the greater leaf production, plantlet vigor and significantly higher shoot multiplication in WPM basal medium, supplemented with auxin NAA, indicated that WPM medium may be the better culture media for $E$. urophylla $\times E$. grandis hybrid. 
At the culture initiation stage, shoots kept over a month produced leaf calluses and wilted. Subculturing to fresh media was needed to maintain shoot vigor and production of new shoots without leaf calluses. The shoots stabilised after a few subculturing cycles and could be kept on the same media for two months without wilting or callusing. A one month subculture cycle yielded sufficiently rigid shoots for shoot multiplication or in vitro rooting.

\section{In vitro rooting}

Half strength MS basal medium is a commonly used medium for rooting of Eucalyptus shoots (Oliveira et al. 2017, Ma et al. 2016). Supplementing half strength MS basal media with increasing concentrations of $0.5 \mathrm{mg} \mathrm{L}^{-1}$ IBA increased the percentage of shoots that rooted, two times of the control, in which $40 \%$ of shoots rooted in vitro (Table 2, Figure 2). The highest number of roots per explants (5.3 \pm 1.3 ) was observed in media with $1.0 \mathrm{mg} \mathrm{L}^{-1}$ NAA followed by $0.5 \mathrm{mg} \mathrm{L}^{-1}$ IBA. Root counts at all IBA and NAA supplementation levels were greater than that of control $(2.0 \pm 0.8)$, however the differences were not significant. Both auxin supplementations induced longer roots, with $2.0 \mathrm{mg} \mathrm{L}^{-1} \mathrm{NAA}$, yielding the longest roots (1.3 $\pm 0.4 \mathrm{~cm})$. However, root length increments measured at all auxin supplementation levels were not significantly different from each other or control $(0.5 \pm 0.3 \mathrm{~cm})$. Supplementation at higher IBA concentrations tended to decrease root growth, however no significant differences were detected between the results.

The study found $0.5 \mathrm{mg} \mathrm{L}^{-1} \mathrm{IBA}$ in half strength MS basal medium as the best medium (with $87 \%$ rooting) for in vitro rooting of E. urophylla $\times$ E. grandis hybrid, where highest percentage of shoot rooted, sufficient number of root produced per shoot and root elongation were observed. The finding is similar to Oliveira et al. (2017) but with higher rooting percentage. Maximum rooting of other Eucalyptus hybrids were reported at different IBA concentrations, e.g., $75 \%$ rooting on half strength MS medium with $1.0 \mathrm{mg} \mathrm{L}^{-1}$ IBA for E. benthamii $\times$ E. dunni and E. tereticornis $\times$ E. camaldulensis (Bisht et al. 1999, Brondani et al. 2011). In another E. hybrid study (E. grandis $\times$ E. urophylla), different rooting responses were reported. Rooting tests on three different clones produced higher rooting percentages and healthy rooted plantlets in activated charcoal compared to those cultured in IBA. The rooting responses among the three clones were varied, suggesting that clonal differences may also play a role in their performance in tissue culture. The usage of IBA resulted in hyperhydric shoots, scar callus development at the base of stem and abnormal roots (thickened and stunted root) at higher IBA concentration (Jones \& Staden

Table 2 Effects of different type and concentration of plant growth regulators (PGR) on in vitro rooting of Eucalyptus hybrid after 2 weeks in culture

\begin{tabular}{cccc}
\hline Auxin $\left(\mathrm{mg} \mathrm{L}^{-1}\right)$ & $\begin{array}{c}\text { \% of shoots } \\
\text { rooted }\end{array}$ & $\begin{array}{c}\text { Mean no of roots per } \\
\text { explant }\end{array}$ & Root length $(\mathrm{cm})$ \\
\hline 0 & 40 & $2.00 \pm 0.84^{\mathrm{a}}$ & $0.55 \pm 0.22^{\mathrm{a}}$ \\
NAA & 53 & $4.07 \pm 1.15^{\mathrm{a}}$ & $0.83 \pm 0.23^{\mathrm{a}}$ \\
0.5 & 73 & $5.33 \pm 1.28^{\mathrm{a}}$ & $1.02 \pm 0.27^{\mathrm{a}}$ \\
1.0 & 80 & $4.27 \pm 1.19^{\mathrm{a}}$ & $1.26 \pm 0.36^{\mathrm{a}}$ \\
2.0 & 80 & $3.33 \pm 1.07^{\mathrm{a}}$ & $1.16 \pm 0.33^{\mathrm{a}}$ \\
3.0 & & & \\
IBA & 87 & $4.60 \pm 0.97^{\mathrm{a}}$ & $1.12 \pm 0.18^{\mathrm{a}}$ \\
0.5 & 67 & $2.60 \pm 0.68^{\mathrm{a}}$ & $0.72 \pm 0.18^{\mathrm{a}}$ \\
1.0 & 60 & $3.93 \pm 1.20^{\mathrm{a}}$ & $0.72 \pm 0.17^{\mathrm{a}}$ \\
2.0 & 80 & $3.867 \pm 0.92^{\mathrm{a}}$ & $0.73 \pm 0.14^{\mathrm{a}}$ \\
\hline
\end{tabular}

*significant at $\mathrm{p}<0.05$; means with different letters in each column are significantly different (Tukey's HSD test); MS = Murashige and Skoog, IBA = indole-3-butyric acid, $\mathrm{NAA}=$ naphthalene acetic acid 

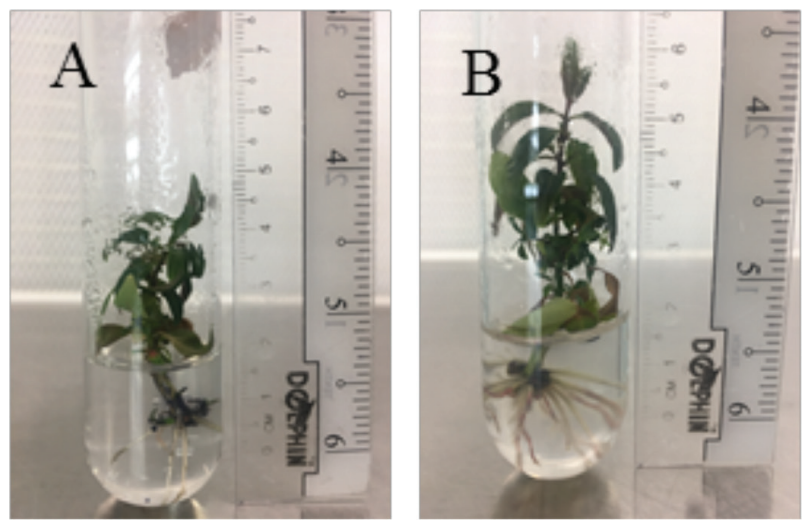

Figure 2 In vitro rooting of Eucalyptus shoots in half strength MS basal media; $\mathrm{A}=$ without auxins (control), $\mathrm{B}=+0.5 \mathrm{mg} \mathrm{L}^{-1} \mathrm{IBA}$

1994). In the present study, the use of IBA at a lower concentration $\left(0.5 \mathrm{mg} \mathrm{L}^{-1}\right)$ did not cause hyperhydric shoot and scar callus development. Healthy well-rooted plantlets with multiple shoots emergence and slender roots were produced at lower IBA concentration. However, scar callus, thick and stunted roots developed at higher IBA concentration. Development of scar callus on the stem has severe implications during plantlets establishment into soil, and hardening. The scar callus will limit the efficient movement of water and nutrients to the plantlets, especially if the root is produced from below the callus (Martin 1985).

\section{Plantlet acclimatisation and growth}

Production of healthy well-rooted plantlets play a vital role during acclimatisation. The plantlets survival depends on their adaptability to balance water lost and water uptake, and to develop autotrophism, since the plantlets are moved from a controlled environment in a culture bottle to ex-vitro condition (Mohammed et al. 1992). Ninety percent survival was recorded for the regenerated Eucalyptus hybrid plantlets after 1 month in the acclimatisation chamber (Figure 3). The excellent acclimatisation and survival rate of E. urophylla $\times E$. grandis hybrid, seen in the present study, has also been reported by Oliveira et al. (2017), where survival of this robust hybrid in the greenhouse was more than $90 \%$. This is similar to the report from Jones and Staden (1993), where the success rate of E. hybrid (E. grandis $\times$ E. urophylla) acclimatisation was near $80 \%$. The differences between these studies were the clones and medium used; Jiffy $7 \circledR$, Plantmax ${ }^{\circledR}$ substrate and pine bark mixture which play a minor role for the plantlets during hardening. The most important factor is to ensure that the plantlets produced during in-vitro must be healthy and functional before acclimatisation process.

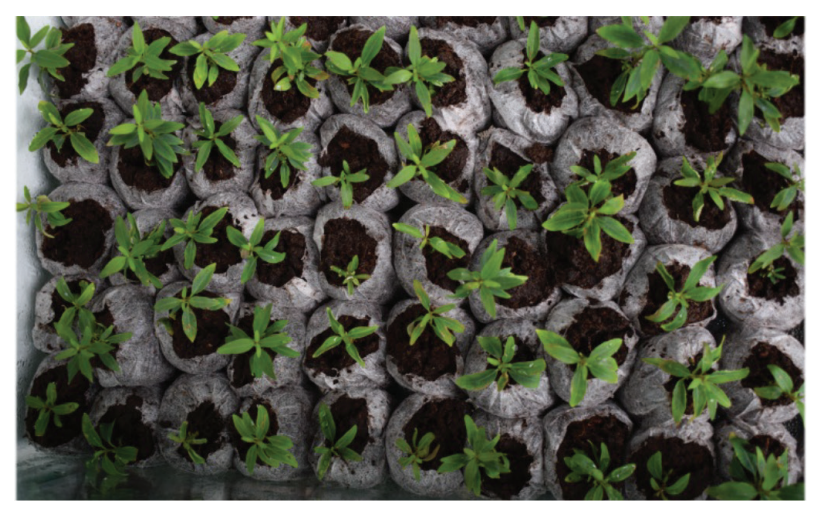

Figure 3 Acclimatised Eucalyptus plantlets at four weeks

The acclimatised plantlets were fast growing. They can reach up to 1-foot-tall after two months of transplanting into suitable potting media with a mixture of baked soil and peat moss (1:1) (Figure 4). According to Mohd Saifuldullah et al. (2019), Eucalyptus hybrid (E. urophylla $\times$ E. grandis) plantlets on baked soil and peat moss (1:1) potting medium had the best growth with a mean height increment of $9.9 \pm 0.9 \mathrm{~cm}$. A total of $10.4 \pm 0.8$ leaves were produced every week until week 7 compared to other media, i.e. baked soil + sand (1:1), topsoil + sand + peat + compost $(1: 1: 1: 1)$ and sand + coir (1:1). The plantlets were ready to be planted in the field at 2 feet tall.

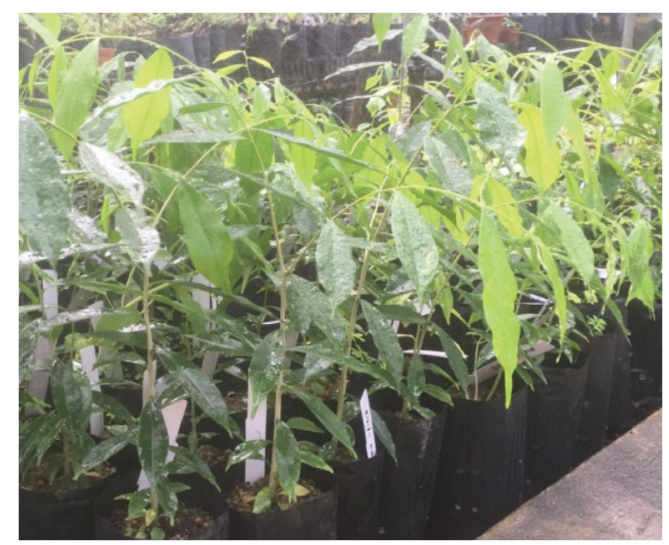

Figure 4 Eucalyptus hybrid plantlets in polybags, grown in the nursery 


\section{CONCLUSION}

In the present study, hybrid of E. urophylla $\times$ E. grandis shoots multiplied well on WPM and MS basal media supplemented with $0.1 \mathrm{mg} \mathrm{L}^{-1}$ BAP, and root production appeared best on half strength MS basal medium supplemented with $0.5 \mathrm{mg} \mathrm{L}^{-1}$ IBA. Following successful acclimatisation of the regenerated plantlets $(90 \%)$ in a weaning chamber for one month, the plantlets grew best on baked soil and peat moss $(1: 1)$ potting media. The results of our study and previous research indicated that different Eucalyptus hybrids, and even same hybrids in different growth environments, may respond differently to PGR and culture media combinations. The results underscored the need to develop hybrid-specific micropropagation protocols by assessing in vitro growth, shoot multiplication and in vitro root production of local Eucalyptus hybrid shoots on a range of media formulations.

\section{ACKNOWLEDGEMENTS}

The authors would like to thank the staff of Forestry Biotechnology Division, FRIM for assistance in the laboratory and nursery studies. The research was funded by the $11^{\text {th }}$ Malaysian Plan and FRIM's board.

\section{REFERENGES}

Ahmad-Zuhaidi Y. 2019. Are We Ready to Commercialise Eucalyptus Hybrid and E. Pellita? FRIM in Focus. FRIM, Kepong.

Batish DR, Singh HP, Kohli RK \& KaUR S.2008. Eucalyptus essential oil as a natural pesticide. Forest Ecology and Management 256: 2166-2174.

Bennett IJ, Mccomb JA, Tonkin CM \& Mcdavid DA J. 1994. Alternating cytokinins in multiplication media stimulates in vitro shoot growth and rooting of Eucalyptus globulus Labill. Annals of Botany 74: 53-58.

Bisht P, Sharma VK, Joshi I \& Kapoor ML. 1999. Micropropagation of newly produced F-1 hybrid of
Eucalyptus (E-tereticornis Sm. XE. camaldulensis DEHN. Southern form). Silvae Genetica 48: 104-108.

Brondani GE, De Wit Ondas HW, Baccarin FJB, Gonçalves AN \& De Almeida M. 2012. Micropropagation of Eucalyptus benthamii to form a clonal micro-garden. In Vitro Cellular Ẽ Developmental Biology 48: 478-487.

Brondani GE, Dutra LF, Wendling I, Grossi F, Hansel FA \& ARAujo MA. 2011. Micropropagation of an Eucalyptus hybrid (Eucalyptus benthamii x Eucalyptus dunnii). Acta Scientiarum. Agronomy 33: 655-663.

Harwood C. 2014. Classical genetics and traditional breeding. Pp 12-34 in Henry R \& Kole C (eds) Genetics, Genomics and Breeding of Eucalypts. CRC Press, Boca Raton.

Henry R \& Kole C. 2014. Genetics, Genomics and Breeding of Eucalypts. CRC Press, Boca Raton.

Jones NB \& Van Staden J. 1994. Micropropagation and establishment of Eucalyptus grandis hybrids. South African Journal of Botany 60: 122-122.

Joshi I, Bisht P, Sharma V \& Uniyal DP. 2003. In vitro clonal propagation of mature Eucalyptus F1 hybrid (Eucalyptus tereticornis Sm. x E. grandis Hill ex. Maiden). Silvae Genetica 52: 110-113.

LEE SS. 2003. Pathology of tropical hardwood plantations in South-East Asia. New Zealand. Journal of Forest Science. 33: 321-335.

Ma S, Car C \& Liu J. 2016. A study on the tissue culture of Eucalyptus urophylla $x$ Eucalyptus grandis. International Journal of Simulation-Systems, Science E् Technology 17: 27.1-27.5.

Martin C. 1985. Plant breeding in vitro. Endeavour 9: 81-86.

Mohammed GH, Gillies SL \& Vidaver WE. 1992. Ex vitro photosynthetic activity in plantlets of tissue-cultured douglas-fir. Tree Physiology 10: 403-410.

Mohd-Saifuldullah AW, Nor-Hasnida H, Nazirah A et al. 2019. Effects of different potting media on the performance of Eucalyptus hybrid tissue culture plantlets under nursery conditions. Transactions of The Malaysian Society of Plant Physiology. 26: 303-306.

Murashige T \& Skoog F. 1962. A Revised Medium for Rapid Growth and Bio Assays with Tobacco Tissue Cultures. Physiologia Plantarum Volume 15, Issue 3: 473-497. https://doi.org/10.1111/j.1399-3054.1962.tb08052.

Oliveira CD, Degenhardt-Goldbach J, De França-Bettencourt GM, Amano E, Franciscon L \& Quoirin M. 2017. Micropropagation of Eucalyptus grandis $\times$ E. urophylla AEC 224 clone. Journal of Forestry Research 28: 29-39.

Xie Y, Arnold RJ, Wu Z, Chen S, Du A \& Luo J. 2017. Advances in Eucalypt research in China. Frontiers of Agricultural Science and Engineering. 4: 380-390. 